\title{
Microsatellite analysis of serum DNA in patients with oral squamous cell carcinoma
}

\author{
YOSHIDOU KAKIMOTO, NOBUHARU YAMAMOTO and TAKAHIKO SHIBAHARA
}

\author{
Department of Oral and Maxillofacial Surgery, Tokyo Dental College, 1-2-2 Masago, Mihama-ku, Chiba 261-8502, Japan
}

Received March 28, 2008; Accepted May 9, 2008

DOI: 10.3892/or_00000129

\begin{abstract}
The purpose of this study was to assess the possibility of prognosis of oral squamous cell carcinoma by microsatellite blood assay. Altered microsatellite DNA in the blood of cancer patients may provide a novel method for tumor detection. DNA from normal and tumor tissues and serum obtained at two time-points (preoperatively and postoperatively) in 20 patients with oral squamous cell carcinoma was examined at 9 microsatellite loci on chromosomes 2, 3, and 21 by polymerase chain reaction (PCR)-based analysis of loss of heterozygosity (LOH). Eighteen patients (90\%) showed microsatellite alterations in serum DNA identical to those in the corresponding tumor DNA. Among those showing allelic imbalance preoperatively (18 patients, 90\%), 8 patients (44\%) showed no evidence of allelic imbalance in serum postoperatively, and these showed no recurrence or distant metastasis. In 10 patients, allelic imbalance was detected postoperatively in serum. Seven $(70 \%)$ out of these 10 patients showed an allelic imbalance at both time-points (preoperatively and postoperatively), and these patients had a poor prognosis. In conclusion, this study suggests that blood testing for circulating tumor genetic markers may provide valuable prognostic information and a guide for future therapy.
\end{abstract}

\section{Introduction}

Squamous cell carcinoma (SCC) is the most common malignant tumor of the oral cavity. To date in this department, microsatellite analysis has been done in primary oral SCCs (1-4). However, as yet, no useful gene marker has been identified for the prognosis or determination of degree of malignancy of this disease. Oral squamous cell carcinoma is likely to metastasize to other organs, so the early detection of metastases is crucial.

Correspondence to: Dr Takahiko Shibahara, Department of Oral and Maxillofacial Surgery, Tokyo Dental College, 1-2-2 Masago, Mihama-ku, Chiba 261-8502, Japan

E-mail: sibahara@tdc.ac.jp

Key words: oral squamous cell carcinoma, allelic imbalances, circulating tumor DNA, microsatellite alteration, prognosis
Carcinogenesis is believed to occur due to the cumulative effect of abnormalities in oncogenes and tumor suppressor genes occurring as a result of erroneous DNA repair (5). Many studies have examined the feasibility of obtaining a diagnosis of cancer based on genetic mutation, for which it is necessary to obtain sample tissue, either during surgical resection or by means of biopsy $(6,7)$. Serum from cancer patients, however, offers a less invasive and easy-to-use diagnostic tool (8). A holy grail for many clinical investigators has been the development of a blood test for cancer control.

Allelic imbalances on particular chromosomes, indicating the absence of tumor suppressor genes, have been detected as a loss of heterozygosity ( $\mathrm{LOH})$ or microsatellite instability (MSI) $(6,7)$ in serum DNA from patients with a variety of malignant tumors, including non-small cell carcinoma of the lung, renal cell carcinoma, and carcinomas at other sites (9-13). Recently, Nawroz et al identified allelic imbalances in oral SCC patient serum using allelotype analysis $(8,14)$, and demonstrated that structural abnormalities in tumorous DNA might provide important prognostic information.

We hypothesized that circulating tumor DNA in blood was a metastasis-predictive factor. The purpose of this study was to determine the feasibility of obtaining a prognosis of oral squamous cell carcinoma by microsatellite blood assay.

\section{Materials and methods}

Tissue samples. Twenty patients (11 men and 9 women; mean age, 62.4 years; range, 33-80 years) who underwent primary oral SCC resection at the Department of Oral and Maxillo-facial Surgery in Tokyo Dental College between 2004 and 2006 were selected to participate in the present study (Table I). Informed consent was obtained from all patients, and our protocol was reviewed and approved by the institutional review board of Tokyo Dental College.

Histopathological diagnosis of each malignant tissue was performed according to the World Health Organization criteria (15). Clinicopathologic staging was determined according to the TNM classification of the International Union against Cancer (16). Half the patients received no chemotherapy, while the other half received an average of $30 \mathrm{mg}$ peplomycin preoperatively. In addition, no radiotherapy was given preoperatively or postoperatively in any of the cases. None of the patients showed distant metastasis at the initiation of the study. No patients underwent blood transfusion. 
Table I. Summary of clinical features in 20 patients with oral SCCs.

\begin{tabular}{|c|c|c|c|c|c|c|c|c|}
\hline Case & Gender & Age & Site & $\mathrm{T}$ & $\mathrm{N}$ & Stage & Clinical outcome & Duration (months) \\
\hline 1 & M & 60 & Gingiva & 2 & 0 & - & Survival & 35 \\
\hline 2 & $\mathrm{M}$ & 41 & Tongue & 3 & $2 b$ & - & Survival & 34 \\
\hline 3 & M & 62 & Oral floor & 2 & 1 & - & Survival & 34 \\
\hline 4 & M & 64 & Oral floor & 4 & $2 b$ & - & Death $^{\mathrm{a}}$ & 7 \\
\hline 5 & M & 58 & Tongue & 1 & 1 & - & Metastasis & 33 \\
\hline 6 & M & 33 & Tongue & 2 & 1 & - & Survival & 21 \\
\hline 7 & M & 80 & Tongue & 1 & 0 & - & Survival & 28 \\
\hline 8 & $\mathrm{~F}$ & 72 & Gingiva & 2 & $2 \mathrm{a}$ & - & Survival & 34 \\
\hline 9 & $\mathrm{~F}$ & 55 & Gingiva & 3 & $2 \mathrm{a}$ & - & Recurrence & 29 \\
\hline 10 & $\mathrm{~F}$ & 69 & Gingiva & 4 & $2 \mathrm{a}$ & - & Metastasis & 27 \\
\hline 11 & $\mathrm{~F}$ & 66 & Mucosa & 2 & 1 & - & Survival & 35 \\
\hline 12 & M & 63 & Tongue & 1 & 0 & - & Survival & 34 \\
\hline 13 & $\mathrm{M}$ & 73 & Gingiva & 4 & $2 b$ & - & Survival & 34 \\
\hline 14 & $\mathrm{~F}$ & 61 & Mucosa & 4 & $2 b$ & - & Metastsis & 32 \\
\hline 15 & M & 61 & Gingiva & 2 & 1 & - & Survival & 33 \\
\hline 16 & $\mathrm{~F}$ & 73 & Gingiva & 3 & $2 \mathrm{a}$ & - & Death $^{\mathrm{b}}$ & 8 \\
\hline 17 & $\mathrm{~F}$ & 66 & Mucosa & 1 & 0 & - & Survival & 29 \\
\hline 18 & M & 68 & Tongue & 1 & 1 & - & Death $^{\mathrm{b}}$ & 9 \\
\hline 19 & $\mathrm{~F}$ & 63 & Tongue & 2 & 0 & - & Survival & 22 \\
\hline 20 & $\mathrm{~F}$ & 60 & Gingiva & 4 & $2 b$ & - & Survival & 20 \\
\hline
\end{tabular}

$\mathrm{M}$, male; F, female; $\mathrm{T}$, primary tumor; $\mathrm{N}$, the regional lymph nodes metastasis, lymph node metastasis (postoperatively); ${ }^{\mathrm{a}}$ respiratory insufficiency; ${ }^{b}$ multiple organ dysfunction.

Table II. Microsatellite markers.

\begin{tabular}{|c|c|c|c|}
\hline Markers & Locations & Size of PCR products (bp) & Sequence of primers \\
\hline D2S1327 & $2 q 32-35$ & 162 & $\begin{array}{l}\text { 5'-TGACCAGGGGAAGATACTGA-3' } \\
\text { 5'-TGAATTGAATAATAACACTCTGTGC-3' }\end{array}$ \\
\hline D2S206 & $2 q 36$ & $123-151$ & $\begin{array}{l}\text { 5'-TTAAAAATTAAGTAGGCTTTTGGTT-3' } \\
\text { 5'-GTCCTCATGTGTTTATGCTGT-3' }\end{array}$ \\
\hline D3S1007 & $3 \mathrm{p} 25$ & 81 & $\begin{array}{l}\text { 5'-GAAGGGTCACTTGAGTCTAGGAG-3' } \\
\text { 5'-ATTTGCCACCATGCCTGGCTAG-3' }\end{array}$ \\
\hline D3S1079 & $3 \mathrm{p} 13$ & 136 & $\begin{array}{l}\text { 5'-GGGAGATAGGTAGTATCATCT-3' } \\
\text { 5'-ATCTACCATTAAGGCAACCTG-3' }\end{array}$ \\
\hline D3S966 & $3 \mathrm{p} 21.3$ & 147 & $\begin{array}{l}\text { 5'-TACCTCCTCACTGTTTCATATTAG-3' } \\
\text { 5'-CACATAGTATGTCTCGGCTAACAG-3' }\end{array}$ \\
\hline $\mathrm{D} 21 \mathrm{~S} 236$ & $21 \mathrm{q} 11.1$ & $104-128$ & $\begin{array}{l}\text { 5'-CCCAAATAAAAAAGAGAACAG-3' } \\
\text { 5'-CTAAAGAGGACTTCAGAGTAAGG-3' }\end{array}$ \\
\hline D21S11 & $21 \mathrm{q} 21$ & $172-264$ & $\begin{array}{l}\text { 5'-GTGAGTCAATTCCCCAAG-3' } \\
\text { 5'-GTTGTATTAGTCAATGTTCTCC-3' }\end{array}$ \\
\hline D21S1254 & $21 \mathrm{q} 22.1$ & 265 & $\begin{array}{l}\text { 5'-AAATACTGATGATCCTTAATTTTGG-3' } \\
\text { 5'-GGTGGCTGAGCGAGAC-3' }\end{array}$ \\
\hline D21S369 & $21 \mathrm{q} 11.1$ & $173-201$ & $\begin{array}{l}\text { 5'-ATGGCCTTGGCTAAATGCTG-3' } \\
\text { 5'-CTAAGCTGATATGGTAAGTACA-3' }\end{array}$ \\
\hline
\end{tabular}




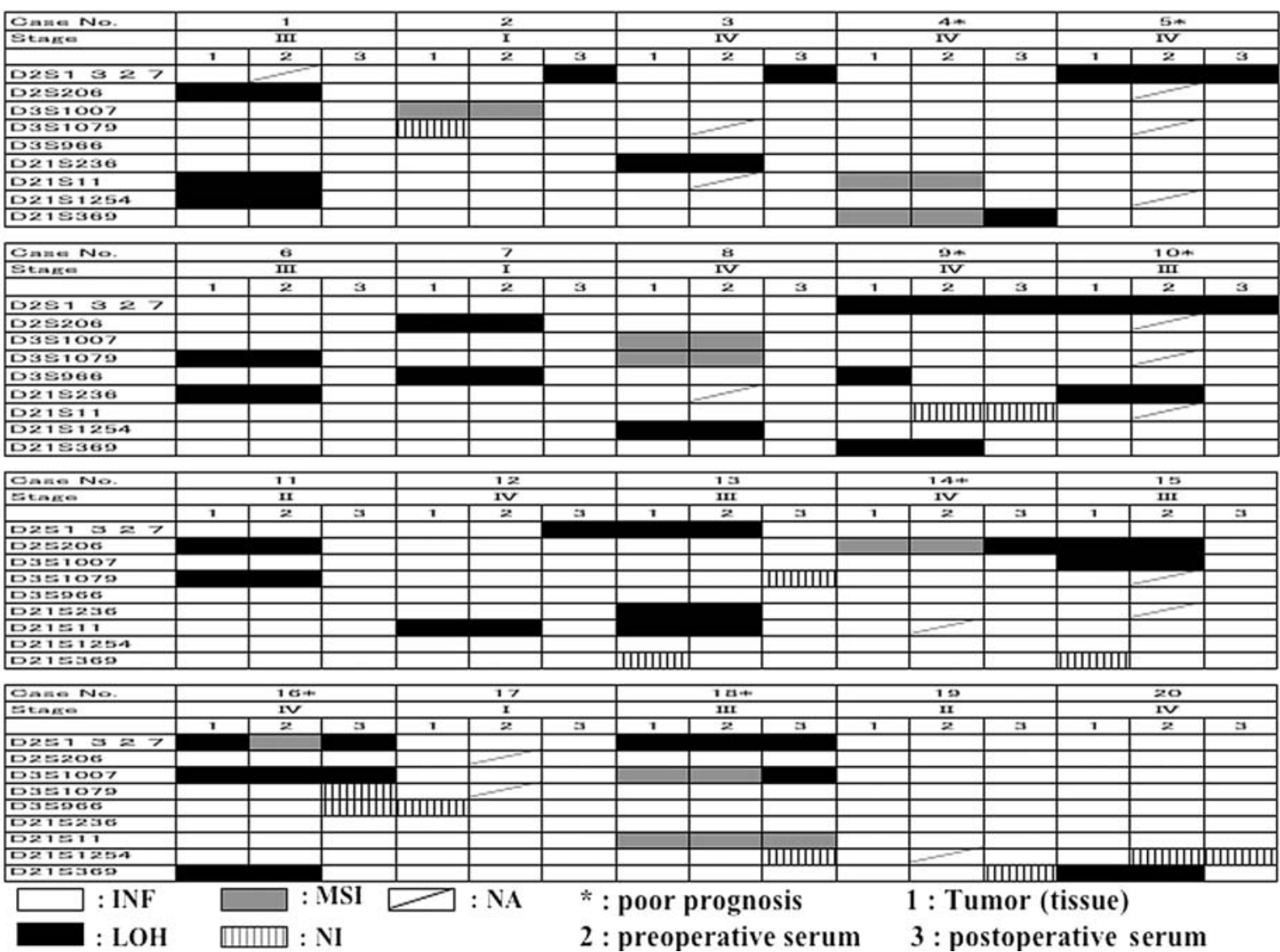

Figure 1. Deletion mapping of chromosomes 2, 3 and 21 in 20 patients with oral SCC. Case numbers are shown on the top and 9 microsatellite markers are shown on the left. DNA was analyzed in serum (preoperative and postoperative) in normal and tumor tissues. Heterozygosity is indicated as INF, homozygosity as NI and not-amplified as NA.

DNA extraction and microsatellite analysis. Peripheral $2 \mathrm{ml}$ blood samples were obtained preoperatively and at one month postoperatively. Blood samples were centrifuged in EDTA for $10 \mathrm{~min}$ at $3,000 \mathrm{~g}$ to obtain serum from the supernatant immediately. Individual primary oral SCC samples and corresponding normal tissues were obtained from 20 patients at surgical resection. Tumor samples were trimmed to remove normal fibrous tissue, and part of each was frozen and stored at $-80^{\circ} \mathrm{C}$ for DNA extraction. Normal tissue from each patient was used to obtain control DNA.

DNA was extracted from tissue and serum using the QIAamp ${ }^{\circledR}$ Blood and Tissue Kit (Qiagen Inc., Hilden, Germany) according to the manufacturer's instructions. Extracted DNA was eluted in $100 \mu 1$ sterile water and stored at $-80^{\circ} \mathrm{C}$ until analysis.

Nine microsatellite markers (D2S1327, D2S206, D3S1007, D3S1079, D3S966, D21S236, D21S11, D21S1254, and D21S369) recently reported to be frequent loci showing allelic imbalances in primary oral SCCs were investigated for allelic imbalance (Table II) (2-4). DNA fragments were amplified by polymerase chain reaction (PCR) in a final volume of $10 \mu 1$ containing 0.25 units HotStarTaq ${ }^{\circledR}$ DNA polymerase (Qiagen) in 10X PCR buffer [50 mM KCL, $10 \mathrm{mM}$ Tris- $\mathrm{Cl}$ (pH 8.0), $1.5 \mathrm{mM} \mathrm{MgCl}_{2}$ ], $0.2 \mathrm{mM}$ deoxynucleotide triphosphate, $0.2 \mu \mathrm{M}$ each primer, $2.5 \mathrm{mM} \mathrm{MgCl}_{2}$ and $2.5 \mathrm{ng}$ genomic DNA. The manufacturer's amplification protocol specified initial denaturation for $15 \mathrm{~min}$ at $94^{\circ} \mathrm{C}$, 40 cycles of $20 \mathrm{sec}$ each at $94^{\circ} \mathrm{C}, 30 \mathrm{sec}$ at $62^{\circ} \mathrm{C}, 30 \mathrm{sec}$ at $72^{\circ} \mathrm{C}$, followed by a final extension step of $72^{\circ} \mathrm{C}$ for 6 min (17). After dilution with an adequate volume of formamidedye mixture (95\% formamide, $20 \mathrm{mM}$ EDTA, $0.05 \%$ bromophenol blue and $0.05 \%$ xylene cyanol), the PCR products were heat-denatured $\left(94^{\circ} \mathrm{C}, 5 \mathrm{~min}\right)$, chilled on ice, and electrophoresed on $6 \%$ urea-formamide-polyacrylamide gel at $3 \mathrm{~W}$ for 2-3 h, depending on fragment size. Silver staining of the gels was performed using the DNA Silver Staining Kit (GE Healthcare UK Ltd., Buckinghamshire, UK).

The normal pattern at each microsatellite in each individual was defined as the pattern in each corresponding normal tissue. Using National Institute of Health (NIH) analysis software (Image version 1.62, Dr W. Rasband, NIH, Bethesda, MD, USA), LOH was assessed by scanning densitometry and diagnosed where signal intensity in tumor DNA was less than that in normal DNA from the same patient. A reduction in signal intensity of $>50 \%$ in a tumor sample compared with that in a normal counterpart was required as the criterion for the presence of LOH. MSI in the DNA samples was assessed as positive in those cases where additional bands in the tumor sample were not observable in the corresponding normal samples, and in those cases which showed a band shift in the tumor sample that contrasted with the pattern of the corresponding normal bands. Heterozygosity is indicated as INF, homozygosity as NI and not-amplified as NA. PCR examinations were performed 3 times to confirm allelic imbalance in each patient. 


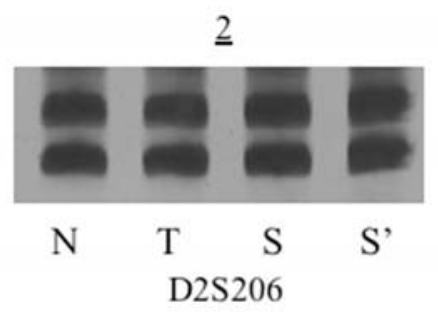

ROH example

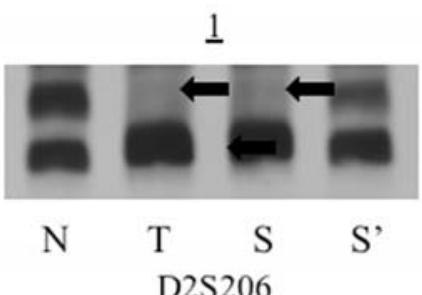

good prognosis example

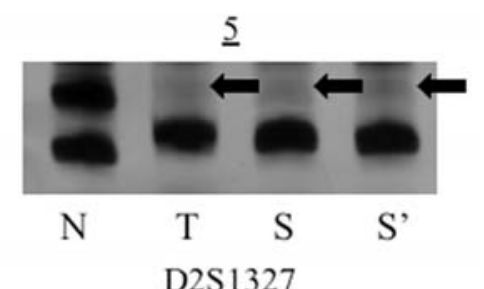

poor prognosis example
LOH: Loss of heterozygosity

$\mathrm{ROH}$ : Retention of heterozygosity

$\begin{array}{ll}\mathrm{N} & : \text { Normal DNA } \\ \mathrm{T} & : \text { Tumor DNA (tissue) } \\ \mathrm{S} & : \text { Circulating tumor DNA (preoperative serum) } \\ \mathrm{S} & \text { : Circulating tumor DNA (postoperative serum) }\end{array}$

Figure 2. Microsatellite polymorphism analysis in oral SCC specimens. Case numbers are shown above, and locus symbols are indicated below. Paired normal $(\mathrm{N})$ and tumor (tissue, preoperative serum and postoperative serum) samples demonstrating loss of upper allele (LOH).

Prognosis was defined as recurrence, metastasis or death, and a prospective $>1$-year follow-up was scheduled to commence following surgery. The relationship between allelic imbalance and prognosis was investigated.

Statistical analysis. Significant differences were calculated by Fisher's exact test. One-tailed P-values $<0.05$ were considered statistically significant.

\section{Results}

Microsatellite analysis. Forty serum samples were collected from 20 subjects at two time-points (preoperatively and postoperatively). Genomic DNA from 20 pairs of tumor and normal samples were extracted. Overall, 80 DNA samples (40 serum samples and 40 tissue samples) were evaluated by microsatellite analysis.

Deletion mapping of chromosomes 2, 3 and 21 in 20 patients with oral SCC is summarized in Fig. 1. Sporadic allelic imbalances in DNA from tumor tissues were observed in 18 of the patients $(90 \%)$ on at least one or more loci examined. At least one allelic imbalance was also detected in the serum DNA in all of the same 18 patients (100\%). A high frequency of allelic imbalance was observed at D2S1327 (on $2 \mathrm{q} 32-35$ ) in tumor tissue in 6 patients (30\%), at D2S1327 (on $2 \mathrm{q} 32-35)$ in preoperative serum in 6 patients (30\%), and at D2S1327 (on 2q32-35) in postoperative serum in 8 patients $(40 \%)$. Typical examples of LOH are shown in Fig. 2. No significant correlation between allelic imbalance and clinical status was noted. Because NA cannot be carried out by PCR, and there was only a small quantity of DNA.

All most patients with an allelic imbalance in tumor DNA also had the same imbalance in serum DNA, suggesting that detection of an allelic imbalance in serum DNA indicates the presence of a tumor (Fig. 1).

Circulating tumor DNA was detected preoperatively in 18 patients $(90 \%)$ and postoperatively in 10 patients
(50\%). Among the patients showing an allelic imbalance preoperatively (18 patients, $90 \%$ ), 8 patients (44\%) showed no evidence of allelic imbalance in serum postoperatively, and these showed no recurrence or distant metastasis. Allelic imbalance was detected postoperatively in 10 patients. Seven out of these 10 patients $(70 \%)$ showed allelic imbalance at both time-points on same locus (preoperatively and postoperatively), and these patients had a poor prognosis.

The most commonly detected region harboring an allelic imbalance in tumor tissue samples and both pre- and postoperative blood samples was at the D2S1327 locus on 2q32-35, where CASP8, CASP10, ADAM23, BARD1, SMARCAL1 and XRCC5, all tumor suppressor genes (TSGs), are in close proximity (18).

\section{Discussion}

In this study, we detected circulating tumor DNA in patients with oral SCC by microsatellite analysis. The results showed that these alterations in serum DNA were almost (90\%) identical with tumor DNA alterations. In this study, circulating tumor DNA in the serum of patients with oral SCC has been shown to reflect the genomics of tumor DNA. The use of microsatellite polymorphic markers to identify and characterize circulating tumor DNA in oral SCC patients was first reported by Nawroz et al (14). Later, a similar study on oral SCC patients was published (19). A few reports have recently suggested that circulating tumor DNA may offer a tool for early diagnosis and prognosis in various site cancers $(12,20-23)$. For example, Hamana et al found that the most frequent marker with allelic imbalance was the IFNA locus at $9 \mathrm{p} 21$, where p16 and p15 tumor suppressor genes frequently mutated, deleted, and methylated in various types of human cancer are in close proximity (19).

In this study, we found in new locus at circulating tumor DNA that microsatellite alterations in serum DNA were predictive of recurrence, metastasis and death. Serum DNA 
in oral SCC may contribute to the earlier detection of recurrence and metastasis. Although the positive microsatellite serum test was not a statistically significant predictor of prognosis, we believe that it may have an important role to play clinically. However, in further research, we need to increase the number of cases investigated to clarify this point and histopathological grading.

All 7 patients with a poor prognosis showed allelic imbalance not only in tumor DNA, but also in serum, and at both time-points. It is important to note in conducting a follow-up that $\mathrm{LOH}$ was positive postoperatively, but negative pre-operatively. This implies that allelic imbalance might not be detected in preoperative serum by preoperative chemo-therapies. In other words, postoperative allelic imbalance may indicate metastasis to another organ. This study was only carried out for a 1-month period postoperatively, this study will be need to incorporate longterm serial observation. In several examples, we analyzed serum DNA postoperatively for 3 months and it showed the same results as for 1-month postoperatively.

The most frequently found allelic imbalances in tumor DNA and pre- and postoperative serum DNA were at the D2S1327 locus on 2q32-35, where CASP8, CASP, ADAM23, BARD1, SMARCAL1, and XRCC5 tumor suppressor genes are in close proximity (18). The functions of these genes include cell apoptosis and cell growth (24-29). Functional studies should be done to clarify the role of these candidate TSGs in oral carcinogenesis. Allelic imbalances at the D2S1327 locus on 2q32-35 were mostly (5/7, 71\%) observed at both time-points (preoperatively and postoperatively) in poor prognosis oral SCCs suggesting that this chromosomal abnormality is associated with inactivation of several tumor suppressor genes, and may contribute to the progression of the disease. In eight other microsatellite markers, frequency of allelic imbalance is low, we need to increase the number of cases investigated to clarify relation with prognosis.

In conclusion, the results of this study suggest that microsatellite analysis at two time-points offers a predictive tool in assessing risk of recurrence, metastasis and death. The establishment of a prognostic method based on detection of allelic imbalance in circulating tumor DNA would offer an accurate and minimally invasive technique that could be used in clinical screening for cancer.

\section{Acknowledgments}

This work was supported by a Research Grant from the Ministry of Education, Science and Culture, Japan (No. 17791497). We would like to thank Associate Professor Jeremy Williams, Tokyo Dental College, for his assistance with the English of this manuscript.

\section{References}

1. Numasawa H, Yamamoto N, Katakura A and Shibahara T: Loss of heterozygosity and microsatellite instability on chromosome $2 \mathrm{q}$ in human oral squamous cell carcinoma. Bull Tokyo Dent Coll 46: 17-25, 2005

2. Yamamoto $\mathrm{N}$, Noma $\mathrm{H}$ and Shibahara T: Allelic imbalance on the long arm of chromosome 21 in human oral squamous cell carcinoma: relationship between allelic imbalances ( $\mathrm{LOH}$ and MSI) and clinicopathologic features. Bull Tokyo Dent Coll 42: 211-223, 2001.
3. Arai K, Shibahara T, Yamamoto $\mathrm{N}$ and Noma H: The presence of candidate tumor suppressor gene loci at chromosome $3 \mathrm{p}$ for oral squamous cell carcinomas. Oral Oncol 38: 763-771, 2002

4. Yamamoto N, Mizoe J, Numasawa H, Tsujii H, Shibahara T and Noma H: Allelic loss on chromosomes 2q, 3p and 21q: possibly a poor prognostic factor in oral squamous cell carcinoma. Oral Oncol 39: 796-805, 2003.

5. Fearon ER and Vogelstein B: A genetic model for colorectal tumorigenesis. Cell 61: 759-767, 1990.

6. Ishwad CS, Ferrell RE, Rossie KM, Appel BN, Johnson JT, Myers EN, Law JC, Srivastava S and Gollin SM: Microsatellite instability in oral cancer. Int J Cancer 64: 332-335, 1995.

7. Ogawara K, Uzawa K, Nakanishi H, Yokoe H, Wang XL, Tanzawa $\mathrm{H}$ and Sato K: Frequent microsatellite instability in oral cancer. Oncol Rep 4: 161-165, 1997.

8. Boland CR: Setting microsatellites free. Nat Med 2: 972-974, 1996.

9. Sozzi G, Musso K, Ratcliffe C, Goldstraw P, Pierotti MA and Pastorino U: Detection of microsatellite alterations in plasma DNA of non-small cell lung cancer patients: a prospect for early diagnosis. Clin Cancer Res 5: 2689-2692, 1999.

10. Gonzalgo ML, Eisenberger CF, Lee SM, Trock BJ, Marshall FF, Hortopan S, Sidransky D and Schoenberg MP: Prognostic significance of preoperative molecular serum analysis in renal cancer. Clin Cancer Res 8: 1878-1881, 2002.

11. Utting M, Werner W, Dahse R, Schubert J and Junker K: Microsatellite analysis of free tumor DNA in urine, serum, and plasma of patients: a minimally invasive method for the detection of bladder cancer. Clin Cancer Res 8: 35-40, 2002.

12. Silva JM, Dominguez G, Garcia JM, Gonzales R, Villanueva MJ, Navarro F, Provencio M, San Martin S, Espana P and Bonilla F: Presence of tumor DNA in plasma of breast cancer patients: clinicopathological correlations. Cancer Res 59: 3251-3256, 1999.

13. Diep CB, Thorstensen L, Meling GI, Skovlund E, Rognum TO and Lothe RA: Genetic tumor markers with prognostic impact in Dukes' stage B and C colorectal cancer patients. J Clin Oncol 21: 820-829, 2003.

14. Nawroz H, Koch W, Anker P, Stroun M and Sidransky D: Microsatellite alterations in serum DNA of head and neck cancer patients. Nat Med 2: 1035-1037, 1996.

15. World Health Organization: Histological Typing of Oral and Oropharyngeal Tumours. No 4. International Histological Classification of Tumours. WHO, Geneva, 1971.

16. UICC TNM Classification of Malignant Tumors. 4th edition. Springer, Berlin, pp16-18, 1987.

17. Nakamoto D, Yamamoto N, Takagi R, Katakura A, Mizoe JE and Shibahara T: Detection of tumor DNA in plasma using whole genome amplification. Bull Tokyo Dent Coll 47: 125-131, 2006.

18. Cengiz B, Gunduz M, Nagatsuka H, Beder L, Gunduz E, Tamamura R, Mahmut N, Fukushima K, Ali Ma, Naomoto Y, Shimizu K and Nagai N: Fine deletion mapping of chromosome 2q21-37 shows three preferentially deleted regions in oral cancer. Oral Oncol 43: 241-247, 2007.

19. Hamana K, Uzawa K, Ogawara K, Shiiba M, Bukawa H, Yokoe H and Tanzawa $\mathrm{H}$ : Monitoring of circulating tumour-associated DNA as a prognostic tool for oral squamous cell carcinoma. Br J Cancer 92: 2181-2184, 2005.

20. Castells A, Puig P, Mora J, Boadas J, Boix L, Urgell E, Sole M, Capella G, Lluis F, Fernandez-Cruz L, Navarro S and Farre A: $\mathrm{K}$-ras mutations in DNA extracted from the plasma of patients with pancreatic carcinoma: diagnostic utility and prognostic significance. J Clin Oncol 17: 578-584, 1999.

21. Kawakami K, Brabender J, Lord RV, Groshen S, Greenwald BD, Krasna MJ, Yin J, Fleisher AS, Abraham JM, Beer DG, Sidransky D, Huss HT, Demeester TR, Eads C, Laird PW, Ilson DH, Kelsen DP, Harpole D, Moore MB, Danenberg KD, Danenberg PV and Meltzer SJ: Hypermethylated APC DNA in plasma and prognosis of patients with esophageal adenocarcinoma. J Natl Cancer Inst 92: 1805-1811, 2000.

22. Sozzi G, Conte D, Mariani L, Lo Vullo S, Roz L, Lombardo C, Pierotti MA and Tavecchio L: Analysis of circulating tumor DNA in plasma at diagnosis and during follow-up of lung cancer patients. Cancer Res 61: 4675-4678, 2001.

23. Taback B, Fujiwara Y, Wang HJ, Foshag LJ, Morton DL and Hoon DS: Prognostic significance of circulating microsatellite markers in the plasma of melanoma patients. Cancer Res 61: 5723-5726, 2001. 
24. Alikhani M, Alikhani Z, Raptis M and Graves DT: TNF-alpha in vivo stimulates opoptosis in fibroblasts through caspase- 8 activation and modulates the expression of pro-apoptotic genes. J Cell Physiol 201: 341-348, 2004.

25. Han JM, Kim YS, Cho GJ, Roh GS, Kim HJ, Choi WJ, Paik WY, Rho GJ, Kang SS and Choi WS: Altered gene expression of caspase-10, death receptor-3 and IGFBP-3 in preeclamptic placentas. Mol Cell 22: 168-174, 2006.

26. Sun Y, Wang Y, Zhang J, Tao J, Wang C, Jing N, Wu C, Deng K and Qiao S: ADAM23 plays multiple roles in neuronal differentiation of P19 embryonal carcinoma cells. Neurochem Res 32: 1217-1223, 2007.
27. Chiba $\mathrm{N}$ and Parvin JD: The BRCA1 and BARD1 association with the RNA polymerase II holoenzyme. Cancer Res 62: 4222-4228, 2005.

28. Bökenkamp A, deJong M, van Wijk JA, Block D, van Hagen JM and Ludwig M: R561C missense mutation in the SMARCAL1 gene associated with mild Schimke immuno-osseous dysplasia. Pediatr Nephrol 20: 1724-1728, 2005.

29. Zhu G, Duffy DL, Turner DR, Ewen KR, Montgomery GW and Martin NG: Linkage and association analysis of radiation damage repair genes XRCC 3 and XRCC5 with nevus density in adolescent twins. Twin Res 6: 315-321, 2003. 